\title{
HUBUNGAN PENGETAHUAN DENGAN SIKAP SISWA SMK KELAS XI JURUSAN TEKNIK PEMESINAN TENTANG HOMOSEKSUAL (Di SMK Negeri 1 Kota Kediri)
}

Rofik Darmayanti, Lutfiana Fadhillah ${ }^{1}$

${ }^{1}$ Akademi Kebidanan Dharma Husada Kediri Jawa Timur

Abstrak

Homoseksual adalah hubungan seks yang dilakukan oleh dua orang yang sama jenis kelaminnya, baik laki-laki maupun perempuan. Kurangnya informasi mengenai homoseksual, berdampak pula pada kurangnya pengetahuan masyarakat mengenai pendidikan seksual, terutama yang berhubungan dengan homoseksualitas. Tujuan penelitian ini adalah mengidentifikasi hubungan pengetahuan dengan sikap siswa SMK Kelas XI Jurusan Teknik Pemesinan di SMK Negeri Kota Kediri.

Desain penelitian yang digunakan adalah korelasional dengan pendekatan cross sectional. Tempat penelitian dilakukan di SMK Negeri 1 Kota Kediri. Populasi adalah seluruh siswa SMK Kelas XI Jurusan Teknik Pemesinan sebanyak 130 siswa dan diperoleh sample sebanyak 98 siswa. Teknik sampling menggunakan simple random sampling. Variabel independen penelitian ini adalah pengetahuan siswa SMK Kelas XI Jurusan Teknik Pemesinan tentang homoseksual dan variabel dependen penelitian ini adalah sikap siswa SMK Kelas XI Jurusan Teknik Pemesinan tentang homoseksual. Penelitian telah dilaksanakan pada tanggal 10 Mei 2017. Pengumpulan data dengan menggunakan kuesioner. Pengolahan data meliputi editing, coding, scoring, dan tabulating. Hasil penelitian ini dianalisis menggunakan chi square.

Hasil penelitian menunjukkan dari 98 responden yang diteliti, mayoritas 67 siswa memiliki pengetahuan cukup dan 98 siswa memiliki sikap positif terhadap homoseksual. Berdasarkan hasil penghitungan dengan program SPSS Versi 24.0 diperoleh nilai $p$ value $=0,011<0,05$ (pada taraf signifikan 5\%). Dengan demikian HI diterima maka dapat disimpulkan ada hubungan pengetahuan dengan sikap siswa SMK Kelas XI Jurusan Teknik Pemesinan tentang homoseksual.

Dalam hal ini diperlukan adanya peningkatan ilmu pengetahuan siswa terhadap homoseksual dengan melakukan penyuluhan kepada seluruh remaja agar terhindar dari perilaku homoseksual.

\section{Kata Kunci : Pengetahuan, Sikap, Siswa SMK Kelas XI, Homoseksual,}




\section{Pendahuluan}

Keberadaan kaum gay adalah fakta. Mereka adalah sebuah realita abad 20 dan telah ada sebelum Indonesia merdeka. Bahkan pada masa kaum Luth juga sudah mengenal perilaku homoseksual. Sebenarnya, kehidupan kaum gay tidak berbeda dengan apa yang biasa kita sebut kaum normal. Mereka makan, minum dan kadang terluka, yang membedakan kaum gay dengan kaum heteroseksual / hubungan seksual lawan jenis adalah dalam hubungan seksualnya. Mereka berhubungan seks secara tidak normal, sehingga menyebabkan penyimpangan seksual. Seperti masyarakat pada umumnya, kaum gay mempunyai tingkat sosial yang terlihat jelas, bahkan mereka sudah digolongkan dengan seseorang yang mempunyai banyak uang. Khusus di kalangan gay, pembagian kelas tampak pada tempat berkumpul untuk minum - minuman keras. Cara berpakaian, berdandan, dan beraksesoris, semuanya berawal pada tingkat penghasilan dan perbedaan kelas mereka.

Kaum gay yang low class biasanya minum di diskotik murah dan tidak terkenal. Mereka juga berpakaian layaknya pasangan normal, dimana laki - laki dengan personaliti seperti wanita atau feminim berpakaian layaknya wanita dengan pakaian yang low class. Sedangkan kaum lesbian, wanitanya berkepribadian seperti laki - laki atau maskulin. Biasanya memakai jaket kulit, rantai, dan sepatu boots. Kaum gay yang high class biasanya lebih menginginkan suatu private party. Dengan private party itu mereka bisa membuat acara sebandel mungkin, sebebas mungkin, dan tentunya sesuai dengan keinginan. Berpenampilan dan berpakaian high class, mereka terkadang mengadakan perjanjian melalui telepon, kemudian bertemu di tempat-tempat minum. Setelah mengobrol beberapa jam, kadang mereka menyewa hotel untuk melakukan hubungan intim. Dalam hal ini, tempat minum mereka berfungsi sebagai tempat untuk bertemu. Namun, sering juga tempat minum mereka dijadikan tempat untuk berbagai perlombaan/kontes. Biasanya, kalau mereka ingin minum, mereka akan datang dengan baju necis, mahal, membawa mobil pribadi dan berpenampilan seperti selebritis. (Azhari, 2008: 26 \& 29)

Kusmiran (2011: 47) menegaskan bahwa semakin merebaknya kaum gay, semakin banyak pula ilmu - ilmu yang mempelajari tentang perilaku homoseksual. Beberapa ahli dapat menyimpulkan bahwa homoseksual merupakan perilaku seksual di mana seseorang tertarik pada orang berjenis kelamin yang sama atau melakukan hubungan seks dengan yang sejenis, baik laki - laki dengan laki - laki, maupun perempuan dengan perempuan berdasarkan ketertarikan mereka. Menurut Kinsey, ada tujuh derajat dari keseimbangan heteroseksual-homoseksual mulai dari exclusively heterosexsual, partly homosexsual, sampai exclusively homoseksual.

Menurut Rahman (2015) Dunia digemparkan dengan dilegalkannya pernikahan sesama jenis di Amerika Serikat menyusul 20 negara lainnya yang sudah terlebih dahulu melegalkannya seperti Belanda dan Kanada. Menurut sebuah analisis 2010 Sensus data AS oleh Williams Institute. Terdapat 901.997 pasangan sesama jenis di Amerika Serikat, dan mereka berada di $99 \%$ dari wilayah Amerika Serikat. 26 juta pengguna Facebook di Amerika ramai-ramai memasang foto profil mereka yang dibubuhi efek pelangi sebagai simbol kemerdekaan mereka mengekspresikan orientasinya.

Data Kementerian Kesehatan pada 2012 menunjukkan bahwa terdapat 1.095.970 Lelaki berhubungan Seks dengan Lelaki (LSL) alias gay yang tersebar di semua daerah. Jawa Barat merupakan provinsi dengan jumlah LSL terbanyak. Sebanyak 300.198 orang yang terindikasi 
merupakan gay. Dari jumlah tersebut, sebanyak 4.895 orang merupakan penderita HIV/AIDS. Sementara itu, Jawa Tengah memiliki penderita gay dengan jumlah 218.227. Dari jumlah itu, sebanyak 11.951 orang terindikasi merupakan penderita HIV/AIDS. Sedangkan DKI Jakarta sebanyak 27.706 warga ibu kota merupakan gay. Dari puluhan ribu gay di ibu kota, sebanyak 5.550 orang diduga menderita HIV/AIDS. Isu LGBT kini kembali merebak. Adanya lembaga konseling Support Group and Resource Center on Sexuality Studies (SGRC) di Universitas Indonesia (UI) membuat kalangan itu kembali eksis di kampus.

Menurut Purba, sesuai jangkauan program HIV/AIDS dari pemerintah, saat ini ada sekitar 6000 kaum LGBT di Surabaya. Di surabaya kaum LGBT sendiri sudah menyebar ke berbagai kalangan. Mulai dari kalangan awam, pelajar, profesional muda, eksklusif muda, kalangan entertaiment, pekerja kantoran, aparat keamanan, hingga anggota legislatif. (Prolgbt, 2016)

Banyaknya populasi gay di wilayah Indonesia, juga mnyebabkan banyaknya penyebaran gay di daerah Kediri. Dari hasil pendataan secara tersembunyi, diperoleh data jumlah komunitas gay di Kediri mencapai sekitar 800 orang. Komunitas ini beranggotakan pria usia sekolah menengah hingga dewasa. Bahkan sejak 2012 telah mendirikan kelompok komunitas dengan inisial GS. Termasuk tempat mangkal komunitas GS biasa dilakukan di kawasan mall dan Cafe Bantaran Sungai Brantas. Komunitas GS telah memiliki pengurus dan sekretariat di wilayah Mojoroto, Kota Kediri. Mayoritas anggotanya anak-anak muda usia di bawah 24 tahun. (Mashudi, 2016)

Dalam buku Lubis (2013: 94-95) Pengaruh dari penyebab homoseksual diatas memunculkan dampak negatif dari Hasil masyarakat terhadap homoseksual seperti halnya menyebabkan penekanan yang diberikan kepada golongan homoseksual dengan melakukan hubungan seksual diluar pikiran. Mereka juga dipertanggungjawabkan terhadap gejala kurang sehat dan berbagai masalah kesehatan seperti AIDS (Acquired Immunodeficiency Syndrome) dan STD (Syndrome Transmitted Deseases). Homoseksual juga tidak diterima di masyarakat bahkan dianggap sebagai orang asing dan tidak mendapatkan layanan seperti orang lain pada umumnya. Dan masih banyak lagi perspektif masyarakat terhadap homoseksual.

Berdasarkan studi pendahuluan yang dilakukan peneliti pada tanggal 12 April 2017 di SMK Negeri 1 Kota Kediri, peneliti melakukan wawancara pada 10 responden siswa laki - laki, didapatkan hasil 5 orang berpengetahuan kurang, 4 orang berpengetahuan cukup, dan 1 orang berpengetahuan baik.

\section{Metode}

Desain penelitian atau yang disebut rancangan penelitian merupakan jenis penelitian yang akan digunakan untuk mencapai tujuan penelitian. Desain penelitian yang dipilih akan membawa konsekuensi pada aturan dari desain tersebut. Pada penelitian ini menggunakan metode penelitian analitik kuantitatif Pendekatan pada penelitian ini menggunakan Cross Sectional,

Populasi yang terdapat pada penelitian ini adalah semua Siswa SMK Kelas XI Jurusan Teknik Pemesinan Negeri 1 Kota Kediri sejumlah 130 Siswa.

Sampel pada penelitian ini adalah sebagian populasi dari siswa SMK Kelas XI Jurusan Teknik Pemesinan Negeri 1 Kota Kediri sejumlah 98 siswa.

Pada penelitian ini menggunakan instrumen penelitian berupa kuesioner 
a. Karakteristik Berdasarkan Umur

Tabel 1 Karakteristik Berdasarkan Umur Di SMK Negeri 1 Kota Kediri

\begin{tabular}{cccc} 
No & Umur (Tahun) & Frekuensi & $\begin{array}{c}\text { Prosentase } \\
\mathbf{( \% )}\end{array}$ \\
\hline 1 & $<15$ tahun & 1 & 1 \\
\hline 2 & $15-17$ tahun & 52 & 53 \\
\hline 3 & $>17$ tahun & 45 & 46 \\
\hline & Total & $\mathbf{9 8}$ & $\mathbf{1 0 0}$
\end{tabular}

b. Karakteristik Berdasarkan Pernah Mendapatkan Informasi

Tabel 2 Karakteristik Berdasarkan Pernah Mendapatkan Informasi di SMK Negeri 1 Kota Kediri

\begin{tabular}{ccccc} 
No & Pernah Mendapatkan Informasi & Frekuensi & Prosentase (\%) \\
\hline 1 & pernah & 98 & 100 \\
\hline 2 & Tidak Pernah & & 0 & 0 \\
\hline \multicolumn{2}{r}{} & Total & $\mathbf{9 8}$ & $\mathbf{1 0 0}$
\end{tabular}

c. Karakteristik Berdasarkan Sumber Informasi

Tabel .3 Karakteristik Berdasarkan Sumber Informasi di SMK Negeri 1 Kota Kediri

\begin{tabular}{clcc} 
No & \multicolumn{1}{c}{ Sumber Informa } & Frekuensi & Prosentase (\%) \\
\hline 1 & Petugas Kesehatan & 6 & 6 \\
\hline 2 & TV, radio, internet & 75 & 77 \\
\hline 3 & Tetangga & 3 & 3 \\
\hline 4 & Brosur, tabloid, koran & 1 & 1 \\
\hline 5 & Lain - lain & 13 & 13 \\
\hline \multicolumn{2}{c}{ Total } & $\mathbf{9 8}$ & $\mathbf{1 0 0}$
\end{tabular}

Tabel .4 Pengetahuan Siswa SMK Kelas XI Jurusan Teknik Pemesinan Tentang homoseksual di SMK Negeri 1 Kota Kediri

\begin{tabular}{lccc} 
& Pengetahuan & Frekuen: & Prosentase ( \\
\hline Baik & & 10 & 10 \\
\hline Cukup & & 67 & 68 \\
\hline Kurang & & 21 & 22 \\
\hline & Total & $\mathbf{9 8}$ & $\mathbf{1 0 0}$
\end{tabular}

Tabel.5 Sikap Siswa SMK Kelas XI Jurusan Teknik Pemesinan Tentang homoseksual di SMK Negeri 1 Kota Kediri

\begin{tabular}{ccccc} 
No & & Sikap & Frekuensi & Prosentase (\%) \\
\hline 1 & Positif & & 55 & 56 \\
\hline 2 & Negatif & & 43 & 44 \\
\hline & & Total & $\mathbf{9 8}$ & $\mathbf{1 0 0}$
\end{tabular}

Tabel.6 Tabel Silang Pengetahuan dengan Sikap Siswa SMK Kelas XI Jurusan Teknik Pemesinan Tentang Homoseksual 


\begin{tabular}{cccccccc}
\multirow{2}{*}{ Pengetahuan } & \multicolumn{4}{c}{ Sikap } & \multicolumn{2}{c}{ Total } \\
\cline { 2 - 6 } & \multicolumn{2}{c}{ Positif } & \multicolumn{2}{c}{ Negatif } & \multicolumn{2}{c}{ Jumlah } & $\%$ \\
\cline { 2 - 6 } & Jumlah & $\mathbf{\%}$ & Jumlah & $\mathbf{\%}$ & 10 & 10,2 \\
\hline Baik & 0 & 0 & 10 & 10,2 & 67 & 68,4 \\
\hline Cukup & 33 & 34,7 & 34 & 33,7 & 21 & 21,4 \\
\hline Kurang & 9 & 9,2 & 12 & 12,2 & $\mathbf{9 8}$ & $\mathbf{1 0 0}$ \\
\hline Total & $\mathbf{4 3}$ & $\mathbf{4 3 , 9}$ & $\mathbf{5 5}$ & $\mathbf{5 6 , 1}$ & $\mathbf{9 5}$
\end{tabular}

Chi Square $\mathrm{p}$ value $=0,011<0,05$

\section{Diskusi}

Pengetahuan Siswa SMK Kelas XI Jurusan Teknik Pemesinan Tentang Homoseksual di SMK Negeri 1 Kota Kediri

Berdasarkan pada tabel penelitian yang terdapat pada tabel.4 dapat diketahui bahwa hasil tertinggi responden sebanyak 67 responden $(68 \%)$ berpengetahuan cukup dan hasil terendah sebanyak 10 responden $(10 \%)$ berpengetahuan baik.

Wawan A, \& Dewi M (2011: 11) menyebutkan bahwa Pengetahuan merupakan hasil tahu dari yang terjadi setelah seseorang melakukan penginderaan terhadap sesuatu objek. Penginderaan terjadi melalui panca indera yaitu penglihatan, pendengaran, penciuman rasa dan raba. Sebagian besar pengetahuan seseorang didapat melalui panca indera mata dan telinga. Pengetahuan merupakan sesuatu yang sangat penting dalam pembentukan perilaku seseorang.

Sesuai dengan pengertian homoseksual, bahwasanya homoseksual merupakan perilaku seksual yang sangat berbahaya baik secara medis maupun secara psikologis. Berbagai agama pun menentang perilaku homoseksual yang menyimpang norma serta aturan yang ada. Kini tidak hanya petugas kesehatan saja yang memberikan wawasan serta pengetahuan tentang homoseksual, tetapi juga orang - orang Contohnya adalah televisi, pakar/ahli, HP, internet.

Internet merupakan salah satu pengetahuan yang didapatkan melalui sumber informasi berupa media elektronik. Banyak manfaat yang didapatkan melalui internet serta banyak juga kerugian dari internet. Pengetahuan tentang homoseksual telah banyak beredar di internet. Hasil tertinggi siswa SMK Kelas XI Jurusan Teknik Pemesinan, sumber informasi tentang homoseksual salah satunya dari internet. Banyak informasi - informasi tentang homoseksual yang terdekatlah yang sangat berperan penting dalam memberikan wawasan perilaku homoseksual. Sehingga semakin banyak mengetahui akibat dari homoseksual, semakin banyak pula masyarakat di Indonesia khususnya kaum lelaki yang menyadari bahwa hal tersebut bukanlah sesuatu yang baik untuk didekati bahkan diminati, karena akan merusak diri sendiri.

Pada tabel dapat diketahui bahwa hasil tertinggi responden sebanyak 75 responden (77\%) sumber informasi dari TV, radio, internet dan hasil terendah sebanyak 1 responden (1\%) sumber informasi dari brosur, tabloid, koran.

Andi, Cahyo (2011) berpendapat bahwa sumber informasi adalah segala hal yang dapat digunakan oleh seseorang sehingga mengetahui sesuatu hal yang baru, yang belum pernah dilakukan dan mempunyai ciri-ciri yaitu dapat dilihat, dibaca dan dipelajari, diteliti, dikaji dan dianalisis, dimanfaatkan dan dikembangkan didalam kegiatan-kegiatan pendidikan, penelitian, laboratorium. Jenis sumber informasi ada tiga, yaitu visual yang merupakan sumber informasi yang dapat dilihat oleh indera penglihatan, dapat berbentuk tuliasan dan gambar. Jenis kedua adalah audio merupakan sumber informasi yang hanya dapat diperoleh melalui indera pendengaran, karena hanya berupa suara dan yang terakhir adalah jenis audiovisual merupakan sumber informasi yang dapat diperoleh baik melalui indera penglihatan maupun pendengaran. menyesatkan melalui internet. Sehingga perlu pemahaman lebih lanjut dalam penggunaan media elektronik berupa internet untuk lebih memahami dengan baik perilaku homoseksual yang menyimpang norma sosial dan aturan perundang - undangan di Indonesia.

Pada tabel tabel.2 maka dapat diketahui bahwa hasil tertinggi responden sebanyak 98 responden $(100 \%)$ sudah pernah mendapatkan informasi tentang homoseksual.

Dalam ensiklopedia yang dimuat pada Wikipedia (2015) menyebutkan bahwa kebebasan informasi 
terutama dalam mendapatkan hak akses informasi yang bersumber dari berbagai media massa seperti televisi, radio, suratkabar, buku dan lain sebagainya. Oleh karena itu kebebasan memperoleh informasi bagi masyarakat dapat menjadi dasar dalam meningkatan keikutsertaan masyarakat dalam mengingat ketersediaan informasi yang memadai dan tentunya akan dapat mendorong masyarakat untuk lebih mampu berpartisipasi.

Kebebasan dalam mendapatkan informasi sudah tidak diragukan lagi. Banyak informasi yang didapat dari berbagai media massa. Tidak dipungkiri, remaja di Indonesia pernah mendapatkan informasi tentang homoseksual dari berbagai media. Dari tabel.2, siswa SMK Kelas XI Jurusan Teknik Pemesinan 100\% pernah mendapatkan informasi tentang homoseksual dengan jumlah 98 responden.

Faktor yang mempengaruhi homoseksual salah satunya adalah umur. Berdasarkan tabel IV.1 maka dapat diketahui bahwa hasil tertinggi responden berumur 15-17 tahun sebanyak 52 responden $(53 \%)$ dan hasil terendah umur responden berumur $<15$ tahun sebanyak 1 responden (1\%).

Menurut Budiman, \& Agus (2013: 4-7) usia akan mempengaruhi daya tangkap dan pola pikir seseorang. Semakin bertambahnya usia, semakin berkembang pula daya tangkap dan pola pikir seseorang. sehingga pengetahuan yang diperoleh semakin berkualitas. Pada usia dewasa, individu akan lebih berperan aktif dalam masyarakat dan kehidupan sosial serta lebih banyak melakukan persiapan demi suksesnya upaya menyesuaikan diri menuju usia tua, selain itu orang usia dewasa akan lebih banyak menggunakan waktu untuk membaca. Kemampuan berpikir, pemecahan masalah, dan daya ingat usia dewasa hampir tidak ada penurunan.

\section{Sikap siswa SMK Kelas XI Jurusan Teknik Pemesinan Tentang Homoseksual di SMK Negeri 1 Kota Kediri}

Berdasarkan tabel.5 dapat diketahui bahwa hasil tertinggi responden berumur 15-17 tahun sebanyak 52 responden $(53 \%)$ dan hasil terendah umur responden berumur $<15$ tahun sebanyak 1 responden $(1 \%)$.

Wawan \& Dewi M (2011: 19) menyebutkan bahwa sikap merupakan sesuatu yang paling penting dalam psikologi sosial, membahas unsur sikap baik sebagai individu maupun kelompok. Banyak penelitian telah dilakukan terhadap sikap yang berkaitan dengan efek dan perannya dalam pembentukan karakter dan sistem hubungan antarkelompok serta pilihan - pilihan yang ditentukan berdasarkan lingkungan dan pengaruhnya terhadap perubahan.

Fakta yang ada menyebutkan bahwa sikap sangat mempengaruhi perilaku dan karakter seseorang. Siswa SMK Kelas XI Jurusan Teknik Pemesinan dengan hasil tertinggi usia 15-17 tahun dalam menyikapi perilaku homoseksual termasuk dalam kategori positif yang artinya tidak mendukung terhadap homoseksual. Hal ini membuktikan bahwa siswa SMK Kelas XI Jurusan Teknik Pemesinan menolak adanya perilaku homoseksual yang menyimpang.

Pada tabel IV.2 dapat diketahui bahwa hasil tertinggi responden sebanyak 98 responden $(100 \%)$ sudah pernah mendapatkan informasi tentang homoseksual.

Menurut Lestari Titik (2015: 12) sikap adalah suatu proses penilaian yang dilakukan seseorang terhadap suatu objek atau situasi yang disertai adanya perasaan tertentu dan memberikan dasar dalam bersikap kepada orang lain untuk membuat respon atau berperilaku dalam cara tertentu atau yang dipilihnya.

Suatu penilaian yang sudah pernah didapatkan akan menghasilkan sebuah respon dan pada penelitian ini, hasil tertinggi siswa SMK Kelas XI Jurusan Teknik Pemesinan 100\% sudah pernah mendapatkan informasi tentang homoseksual. Sehingga siswa SMK Kelas XI Jurusan Teknik Pemesinan menilai dengan sikap yang positif yang artinya menolak adanya homoseksual dan menyikapi bahwa homoseksual tidak terdapat dalam diri SMK Kelas XI Jurusan Teknik Pemesinan, karena perilaku homoseksual merupakan sesuatu yang tidak lazim dan sangat berbahaya jika diminati dan dilakukan.

Pada tabel IV.3 dapat diketahui bahwa hasil tertinggi responden sebanyak 75 responden (77\%) sumber informasi dari TV, radio, internet dan hasil terendah sebanyak 1 responden (1\%) sumber informasi dari brosur, tabloid, koran.

Menurut Allport (1954) yang dikutip oleh Sarwono dan Meinarno (2009) dalam Titik Lestari (2015: 12), bahwa sikap merupakan kesiapan mental, yaitu suatu proses yang berlangsung dalam diri seseorang, bersama 
dengan pengalaman individual masing - masing, mengarahkan dan menentukan respons terhadap berbagai objek dan situasi.

Pengalaman individu yang dilibatkan dengan sikap seseorang akan menghasilkan sebuah respon positif ataupun negatif. Sama halnya dengan siswa SMK Kelas XI Jurusan Teknik Pemesinan. Pengalaman melalui sumber informasi yang ada dari berbagai media massa tentang homoseksual, akan menghasilkan sebuah respon yaitu siswa SMK Kelas XI Jurusan Teknik Pemesinan yang bersikap positif maupun negatif berpengaruh terhadap sumber informasi dari $\mathrm{TV}$, radio, internet yaitu hasil tertinggi sebanyak 75 responden (77\%) mengenai homoseksual. Sehingga sumber informasi mempengaruhi sikap seseorang dalam melakukan sesuatu yang bersifat positif maupun negatif.

Sikap positif maupun sikap negatif juga tergantung pada faktor kebudayaan mempunyai pengaruh besar terhadap pembentukan sikap. Berbagai bentuk media massa seperti televisi, radio, internet, surat kabar, majalah, tabloid, dan lain-lain mempunyai pengaruh besar dalam pembentukan opini dan kepercayaan seseorang. Sebagai tugas pokoknya dalam menyampaikan informasi, media massa membawa pesan-pesan yang berisi sugesti yang dapat mengarahkan opini seseorang. Informasi baru mengenai sesuatu hal memberikan landasan kognitif baru bagi terbentuknya sikap terhadap hal tersebut. Pesan-pesan sugestif yang dibawa oleh informasi tersebut, bila cukup kuat, akan memberi dasar afektif dalam menilai sesuatu hal sehingga terbentuklah sikap.

Pembentukan sikap juga melibatkan faktor dari pengaruh orang lain. Baik itu positif maupun negatif menghasilkan kesan berbeda pada setiap individu dalam pengaruh seseorang. Bagi individu pengaruh tersebut didapatkan dari orang tua, teman dekat, guru, teman kerja, istri, suami, dll.

Pada tabel IV.5 dapat diketahui bahwa hasil tertinggi responden sebanyak 55 responden $(56 \%)$ memiliki sikap positif dan hasil terendah sebanyak 43 responden (44\%) memiliki sikap negatif.

Menurut pandangan Bern dalam Self Perception Theory oleh Ariani Ayu Putri (2014: 29) seseorang yang bersikap positif/negatif terhadap suatu objek sikap, dibentuk melalui pengamatan pada perilaku sendiri. Seseorang yang mempunyai sikap positif terhadap sesuatu maka akan dapat menguasainya dengan baik. Secara garis besar sikap terdiri dari komponen kognitif (ide yang berkaitan dengan pembicaraan), perilaku (Cenderung mempengaruhi respon sesuai dan tidak sesuai), dan emosi (menyebabkan respon - respon yang konsisten).

\section{Hubungan Pengetahuan dengan Sikap Siswa SMK Kelas XI Jurusan Teknik Pemesinan Tentang Homoseksual di SMK Negeri 1 Kota Kediri}

Berdasarkan hasil penelitian yang sudah dilakukan peneliti pada tanggal 10 Mei 2017, pada tabel IV.6 dapat diketahui bahwa responden yang mempunyai pengetahuan baik dengan sikap positif sebanyak 0 responden $(0 \%)$, sedangkan yang berpengetahuan baik dengan sikap negatif sebanyak 10 responden (10,2\%). Responden yang mempunyai pengetahuan cukup dengan sikap positif sebanyak 33 responden (34,7\%), sedangkan yang berpengetahuan cukup dengan sikap negatif sebanyak 34 responden $(33,7 \%)$. Responden yang mempunyai pengetahuan kurang dengan sikap positif sebanyak 9 responden $(9,2 \%)$, sedangkan yang berpengetahuan kurang dengan sikap negatif sebanyak 12 responden $(12,2 \%)$.

Untuk menguji dan mengetahui adanya hubungan pengetahuan dengan sikap siswa SMK Kelas XI Jurusan Teknik Pemesinan Tentang Homoseksual, penguji meneliti dengan menggunakan rumus uji Chi Square dengan program SPSS, didapatkan $p$ value $=0,011$ (dengan derajat kemaknaan $\mathrm{p}<0,05$ ) sehingga $p$ value $=0,011<0,05$, maka $\mathrm{HI}$ diterima artinya ada hubungan pengetahuan dengan sikap siswa SMK Kelas XI Jurusan Teknik Pemesinan Tentang Homoseksual di SMK Negeri 1 Kota Kediri.

Menurut Budiman, \& Agus (2013: 3) pengetahuan merupakan segala sesuatu yang diketahui berkenaan dengan hal mata pelajaran. Proses belajar seseorang dipengaruhi oleh dua faktor yaitu faktor dari dalam seperti motivasi dan faktor luar berupa sarana informasi yang tersedia, serta keadaan sosial budaya. Ariani (2014: 17) juga berpendapat bahwa pengetahuan merupakan hasil rasa keingintahuan manusia terhadap sesuatu dan hasrat untuk meningkatkan kualitas hidup sehingga kehidupan menjadi lebih baik dan nyaman, berkembang sebagai upaya untuk memenuhi kebutuhan manusia baik di 
Rofik Darmayanti : Hubungan Pengetahuan dengan sikap siswa SMK Kelas XI Jurusan Teknik Pemesinan Tentanf Homoseksual (Di SMK Negeri I Kota Kediri)

masa sekarang maupun dimasa depan. Hal ini sudah ditegaskan oleh Notoadmodjo (2010) bahwa sebelum seseorang berperilaku, maka harus tahu terlebih dahulu mengerti manfaat dari perilaku

Pengetahuan siswa SMK Kelas XI Jurusan Teknik Pemesinan tentang homoseksual di SMK Negeri 1 Kota Kediri merupakan dalam batas cukup dengan jumlah 67 responden (68\%) dan hasil tertinggi memiliki sikap yang positif yang artinya menolak adanya homoseksual dengan jumlah 55 responden $(56 \%)$. Siswa SMK Kelas XI Jurusan Teknik Pemesinan membawa sikap yang positif dan menunjukkan pengetahuan yang cukup mengenai homoseksual

\section{DAFTAR PUSTAKA}

Ariani, Ayu Putri. 2014. Aplikasi Metodologi Penelitian Kebidanan dan Kesehatan Reproduksi. Yogyakarta: Nuha Medika

Azhari, Rama. \& Putra K. 2008. Membongkar Rahasia Jaringan Cinta Terlarang Kaum Homoseksual. Jakarta: Hujjah Press

Azwar, S. 2013. Sikap Manusia Teori dan Pengukurannya. Yogyakarta : Pustaka Pelajar Offset.

Budiman. \& Agus Riyanto. 2013. Kapita Selekta Kuesioner Pengetahuan dan Sikap dalam Penelitian Kesehatan. Jakarta: Salemba Medika

Hidayat, A Alimun Aziz. 2014. Metode Penelitian Kebidanan dan Teknik Analisis Data. Jakarta: Salemba Medika

Junaedi, Didi. 2016. Penyimpangan Seksual yang Dilarang Al-Qur'an. Jakarta : Quanta

Lestari, Titik. 2015. Kumpulan Teori untuk Kajian Pustaka Penelitian Kesehatan. Yogyakarta: Nuha Medika

Lubis, Namora L. 2013. Psikologi Kespro Wanita \& Perkembangan Reproduksinya. Jakarta: Kencana

Notoatmodjo, Soekidjo. 2012. Metode Penelitian Kesehatan. Jakarta: Rineka Cipta

Sujarweni, Wiratna. 2014. Metode Penelitian Lengap, Praktis, dan Mudah Dipahami. Yogyakarta: Pustaka Baru Press

\section{Simpulan}

Sebanyak 98 responden, terdapat 67 responden (68\%) mempunyai pengetahuan tentang homoseksual dalam kategori cukup.

Dari 98 responden sebagian besar mempunyai sikap positif tentang homoseksual sebanyak 54 responden (55\%)

Analisis data menggunakan rumus uji Chi Square dengan program SPSS, didapatkan $p$ value $=$ 0,011 (dengan derajat kemaknaan $\mathrm{p}<0,05$ ) sehingga $p$ value $=0,011<0,05$, maka HI diterima artinya ada hubungan pengetahuan dengan sikap siswa SMK Kelas XI Jurusan Teknik Pemesinan Tentang Homoseksual di SMK Negeri 1 Kota Kediri.

Sulistiani, Siska L. 2016. Kejahatan dan Penyimpangan Seksual dalam Perspektif Hukum Islam dan Hukum Positif Indonesia. Bandung: Nuansa Aulia

Suyanto. 2011. Metodologi dan Aplikasi Penelitian Keperawatan. Yogyakarta : Nuha Medika

Wawan, A. \& Dewi M. 2011. Teori Pengukuran Pengetahuan, Sikap, dan Perilaku Manusia. Yogyakarta: Nuha Medika

Andi, Cahyo. 2011. Sumber Informasi. Diakses dari : http://cahyo-andi-s.blog.ugm.ac.id/2011/10/01/sumberinformasi/) [Diakses pada 1 Juni 2017]

Demartoto, Argyo. 2013. Seks, Gender, Seksualitas Gay, dan Lesbian. Diakses dari http://argyo.staff.uns.ac.id/2013/04/24/seks-genderseksualitas-gay-dan-lesbian/) [Diakses pada 25 April 2017]

LGBT, Kabar, 2016. 10 Negara paling ramah dengan Gay dan Lesbian [Online] (Updated 5 Februari 2016) Diakses dari : https://kabarlgbt.org/2016/02/05 /10-negara-paling-ramahdengan-gay-dan-lesbian/ [15 Januari 2017]

Mashudi, Didik, 2016. Ratusan Warga Kediri Jadi Anggota LGBT Wakil Walikota dan Pramuka Ramai-ramai Menolak [Online] (Updated 28 Februari 2016) Diakses dari : http://www.kedirikota.go.id/read/DalamBerita /2016/02/29/3/7/666/Ratusan\%20Warga\%20Kediri\%20Jadi \%20Anggota\%20LGBT\%20Wakil\%20Walikota\%20dan\%20 Pramuka\%20Ramai-ramai\%20Menolak 